$\frac{204}{8-3 c}$

RFP-1852

RFP-1852

July 17, 1972

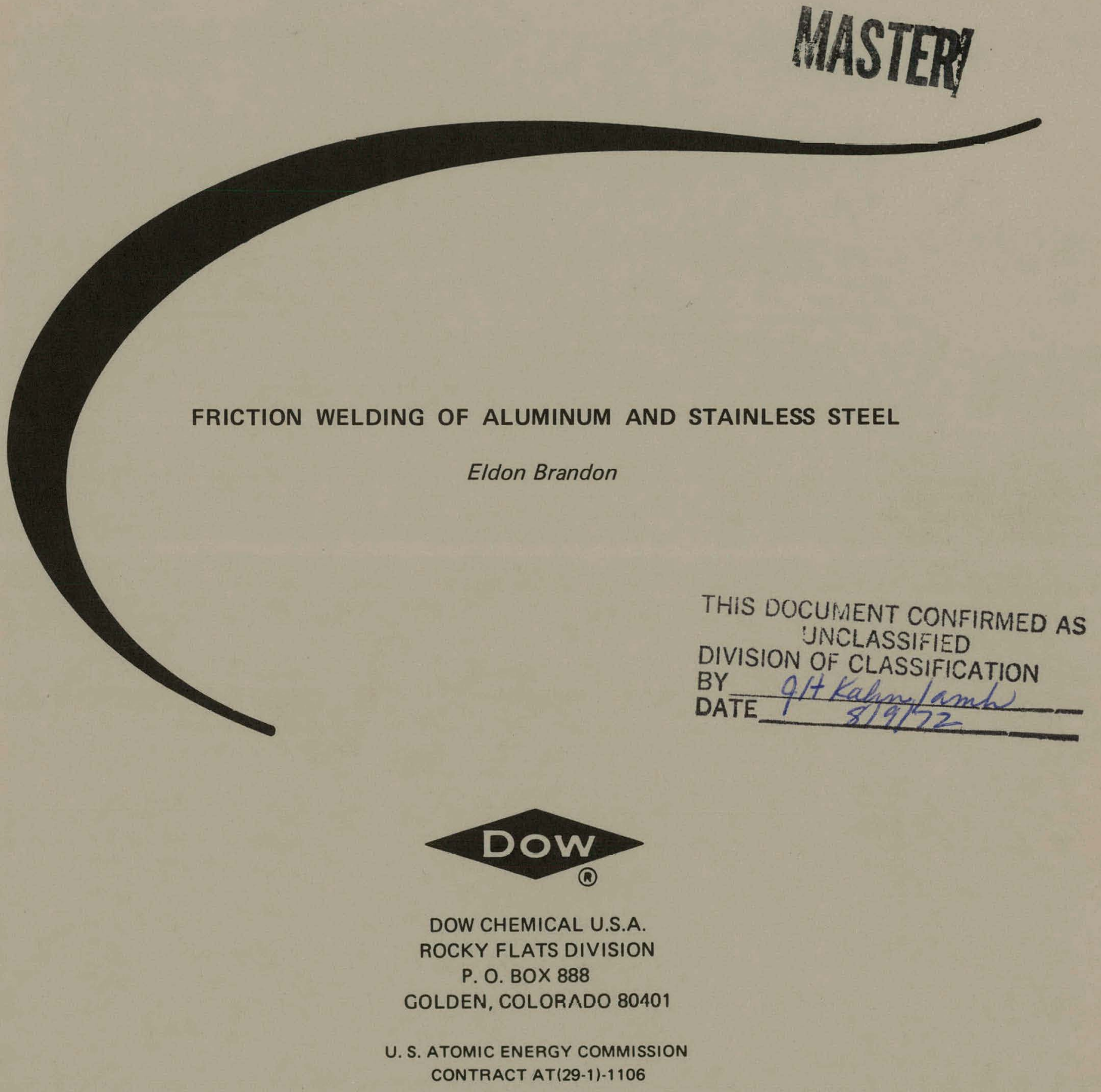




\section{DISCLAIMER}

This report was prepared as an account of work sponsored by an agency of the United States Government. Neither the United States Government nor any agency Thereof, nor any of their employees, makes any warranty, express or implied, or assumes any legal liability or responsibility for the accuracy, completeness, or usefulness of any information, apparatus, product, or process disclosed, or represents that its use would not infringe privately owned rights. Reference herein to any specific commercial product, process, or service by trade name, trademark, manufacturer, or otherwise does not necessarily constitute or imply its endorsement, recommendation, or favoring by the United States Government or any agency thereof. The views and opinions of authors expressed herein do not necessarily state or reflect those of the United States Government or any agency thereof. 


\section{DISCLAIMER}

Portions of this document may be illegible in electronic image products. Images are produced from the best available original document. 


\section{LEGAL NOTICE}

'I'his report was prepared as an account of work sponsored by the United States Government. Neither the United States nor the United States Atomic Energy Commission, nor any of their employees, nor any of their contractors, subcontractors, or their employees, makes any warranty, expressed or implied, or assumes any legal liability or responsibility for the accuracy, completeness or usefulness of any information, apparatus, product or process disclosed, or represents that its use would not infringe privately owned rights.

Printed in the United States of America Available from the

National Techuical Information Service

U. S. Department of Commerce

Springfield, Virginia 22151

Price: Printed Copy $\$ 3.00$; Microfiche $\$ 0.95$ 
Publication Date

J uly 17, 1972
RFP-1852

UC-25.METALS, CERAMICS, AND MATERIALS

TID-4500 (56th Ed.)

\title{
FRICTION WELDING OF ALUMINUM AND STAINLESS STEEL
}

\author{
Eldon Brandon
}

\section{Research and Ecology \\ JOINING GROUP}

\begin{abstract}
NO'TICE
This report was prepared as an account of work sponsored by the United States Government. Neither the United States nor the United States Atomic Energy Cummission, nor any/of their employees, nor any of their contractors, subcontractors, or their employees, makes any warranty, express or implied, or assumes any legal liability or responsibility for the accuracy, completeness or usefulness of any information, apparatus, product or process disclosed, or represents that its use would not infringe privately owned rights.
\end{abstract}

DOW CHEMICAL U.S.A. ROCKY FLATS DIVISION

P. O. BOX 888

GOLDEN, COLORADO 80401

Prepared under Contract AT(29.1).1106

for the

Albuquerque Operations Office

U. S. Atomic Energy Commission 


\section{CONTENTS}

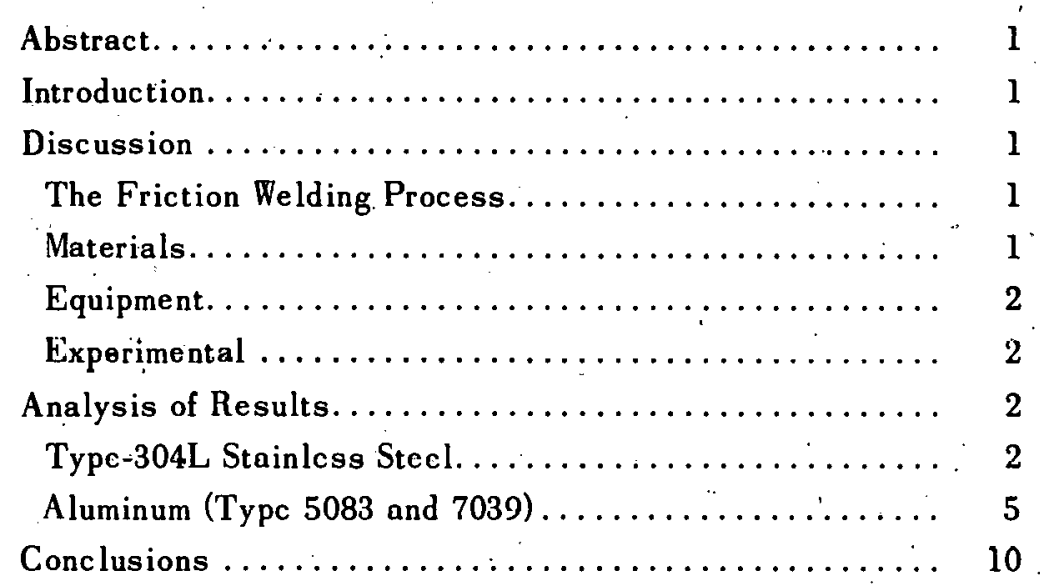




\section{FRICTION WELDING OF ALUMINUM AND STAINLESS STEEL}

\section{Eldon Brandon}

Abstract. Studies were made of friction-wclded cylindrical coupons of aluminum (5083 and 7039) and stainless steel (Type-304L) to check the appli-. cability of friction welding at Rocky Flats Plant. After sectioning the coupons for macroexamination and tensile testing, the effects of various wclding parameters were determined. The criteria for evaluation included mechanical properties, upset (change in length), and flash. Approximate welding parameters were derived and are reported.

The resultant welding flash was approximately twice the original wall thickness. The upset values were 0.7 centimeters in the 0.65 -centimeter wall stainless steel cylinders, and 1.0 centimeters in the 1.25-centimeter wall aluminum cylinders. All 5083 tensile coupons failed in the heat-affected zone; and all 7039 tensilcs failed in the base metal. Failures in all three locations were encountered with the stainless steel (Type-304L). Because of the geometry of the as-welded joint, friction-weld processes are not applicable for current production at Rocky Flats.

\section{INTRODUCTION}

Studies were made to dctcrmine the feasibility and practicality of using friction welding to join various units having a girth weld. Coupons of Type-304L stainless steel and aluminum, Types 7039 and 5083, were evaluated. The coupons were friction-welded by the Caterpillar Tractor Company in Mossville, Illinuis. Of primary concern in the evaluation were extent of the flash, especially on the inside diameter of the weld, the juint soundness, joint geometry, and the mechanical properties of the welds.

\section{DISCUSSION}

\section{The Friction Welding Process:}

Friction welding is a solid-state process in which coalescence can be produced by heat and pressure. A friction weld is accomplished by rotating one part at. relatively high speeds against a stationary member to which it is to be joined. The weld forms upon stoppage of the relative motion between the two parts. ${ }^{1}$

Inertia welding is an adaptation of the frictionwelding process. In this case, one member is clamped in the tailstock of a lathe-type machine. The member remains stationary throughout the welding process. A second member is clamped in the massive headstock (flywheel) with the two members slightly separated. The flywheel is accelerated to a preset speed. Then the motor is disengaged from the flywheel which moves the rotating member into contact with the stationary member with a preset thrust force. The kinetic energy of the rotating flywheel is converted to heat at the sliding interface. The heat and pressure extrude the abutting interfaces. As the relative motion stops, a solid-state bond is formed. The operational variables are the moment of inertia of the flywheel, the rotational speed, and the axial force.

\section{Materials:}

Stainless steelType-304L, extruded and annealed, bar stock, was used. The chemical composition is given in Table $I$.

Aluminum-

Types 5083 and 7039 extruded bar stock were welded, each to itself only. The types are further described as 5083-H32l (strain hardened and low. temperature stress relieved) and 7039-T6 (heat trealed and artificially aged). Chemical compositions are given in Table II.

\footnotetext{
${ }^{1}$ Welding Handbook. Section 3. American Welding Society, Miami, Florida. 1964.
}

TABLE I. Chemical Composition of Stainless Steel (Type 304-L).

\begin{tabular}{lc}
\multicolumn{1}{c}{ Material } & Percent \\
\cline { 3 - 3 } Chromium (Cr) & 18 to 20 \\
Nickel (Ni) & 8 to 10 \\
Carbon (C) & 0.03 (maximum) \\
Manganese (Mn) & 2.0 (maximum) \\
Silicon (Si) & 1.0 (maximum) \\
Phosphorus (P) & 0.045 (maximum) \\
Sulfur (S) & 0.030 (maximum) \\
Iron (Fe) & Balance
\end{tabular}


TABLE II. Chemical Composition of Aluminum (Types 5083 and 7039).

\begin{tabular}{|c|c|c|}
\hline Material & $\begin{array}{c}\text { Type } \\
5083 \\
\text { (percent) }\end{array}$ & $\begin{array}{c}\text { Type } \\
7039 \\
\text { (percent) }\end{array}$ \\
\hline Magnesium (Mg) & 4.0 to 4.9 & 2.3 to 3.3 \\
\hline Manganese (Mn) & 0.3 to 1.0 & 0.1 to 0.4 \\
\hline Ghromium (Cr) & 0.05 to 0.25 & 0.15 to 0.25 \\
\hline $\operatorname{Zinc}\left(\mathrm{Zn}_{\mathrm{n}}\right)$ & 0.25 to $(\max )$ & 3.5 to 4.5 \\
\hline Titanium (Ti) & 0.15 to $(\max )$ & 0.10 to $(\max )$ \\
\hline Silicon (Si) & 0.4 to $(\max )$ & 0.3 to $(\max )$ \\
\hline Iron $(\mathrm{Fe})$ & 0.4 to (max) & 0.4 to $(\max )$ \\
\hline Copper (Cu) & 0.1 to $(\max )$ & 0.1 to $(\max )$ \\
\hline Aluminum ( $\mathrm{Al}$ ) & Balance & Balance \\
\hline
\end{tabular}

\section{Equipment:}

The friction welding was performed for Rocky Flats at the Development Laboratory, Inertia Welder Department, Caterpillar Tractor Company, Mossville, Illinois.

'I'he welder used was a Calerpillar Modcl-150 which has a maximum rated capability of welding a 3.8centimctcr $(\mathrm{cm})$ diameter solid-steel bar stock. Its maximum spindle speed is 8000 revolutions per minute (rpm), and maximum thrust force is 200 kllonewtuns (kN).

\section{Experimental:}

In order to simulate a Lubular butt joint, coupons of the configuration shown in Figure 1 were prepared. The outside diameters of the stainless steel and aluminum were 6.4 and $10.2 \mathrm{~cm}$, respectively.

The welds were made at the counterbored ends using various combinations of the parameters given in Table III. Typical welds were selected for evaluation. Evaluation was by means of physical measurements, metallography, and mechanical tests:

\section{ANALYSIS OF RESULTS}

\section{Type-304L Stainless Steel:}

Figure 2(a) shows the welds made at an axial pressure of 1.32 megapascals $(\mathrm{MPa})$ and with various rotational speeds (1400 through $1900 \mathrm{rpm}$ ). Figure 2(b)

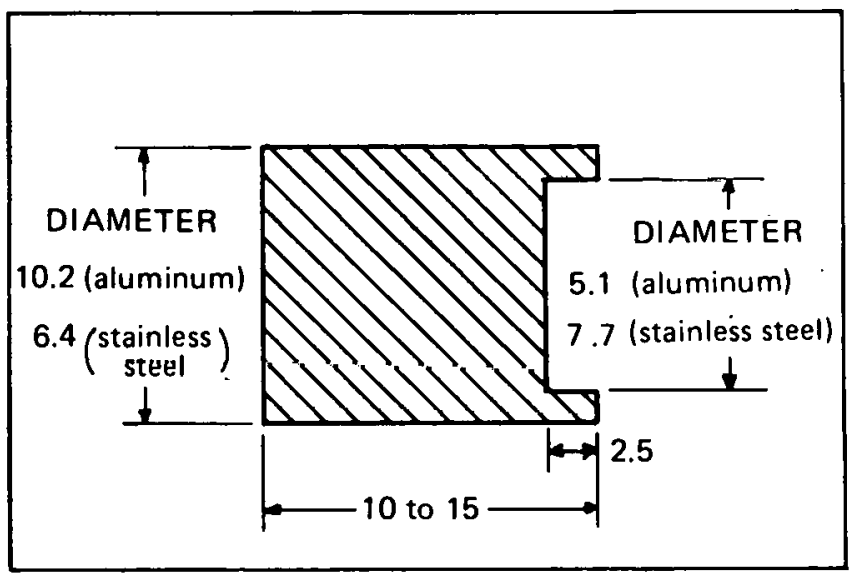

FIGURE 1. Configuration of Coupons for Aluminum and Stainless Steel Friction Welds. (Centimeter Dimensions.)

TADLE III. Pnrnmetora Uned for Frictionn Welding.

\begin{tabular}{|c|c|c|c|}
\hline Material & $\begin{array}{c}\text { Rotational } \\
\text { Speed } \\
\left(\begin{array}{c}\text { revolutions } \\
\text { per minute }\end{array}\right)\end{array}$ & $\begin{array}{c}\text { Thrust } \\
\text { (megapascals) }\end{array}$ & $\begin{array}{c}\text { Moment of } \\
\text { Inertia } \\
\left(\begin{array}{c}\text { kilogram- } \\
\text { meters }\end{array}\right)\end{array}$ \\
\hline $\begin{array}{l}\text { Stainless Steel } \\
\text { ('Type-304L) }\end{array}$ & $\begin{array}{l}1400 \\
1700 \\
2000 \\
2300 \\
2600 \\
2900\end{array}$ & $\begin{array}{l}0.80 \\
1.09 \\
1.32\end{array}$ & 2.14 \\
\hline $\begin{array}{l}\text { Aluminum } \\
\text { (Type 5083-H321) }\end{array}$ & $\begin{array}{l}1380 \\
1430 \\
1480 \\
1530\end{array}$ & 0.38 & 15.6 \\
\hline $\begin{array}{l}\text { Aluminum } \\
\text { (Type 7039.T6) }\end{array}$ & $\begin{array}{l}1300 \\
1380 \\
1430\end{array}$ & 0.38 & 15.6 \\
\hline
\end{tabular}

shows the welds made at a speed of $2900 \mathrm{rpm}$ and with axial pressures of $0.80,1.09$, and $1.32 \Lambda \mathrm{Pa} .^{2}$

Welds $1,4,6,7$, and 8 were sectioned for macroexaminatioñ and tu ublain spccimens for merhanical testing. Photomacrographs of weld-transverse sections were used to determine weld soundness, wcld dimensions, metallurgical flow lines, and extent of the heat-affected zone (HAZ). The dimensional

\footnotetext{
${ }^{2}$ The International System of Units (SI) (metric) are used throughout this repnrt. For conversions: 1 inch $=25.4$ millimeters, 0.22 pounds (force) $=1$ newton $(N), 1$ psi $=133$ pascals $(P a)$ or 1 kilopascal $=0.145$ pounds per square inch, and 23.78 pound. feet $^{2}=1$ kilogram-meter". A pascal replaces the term "newton per meter ${ }^{2} . "$
} 


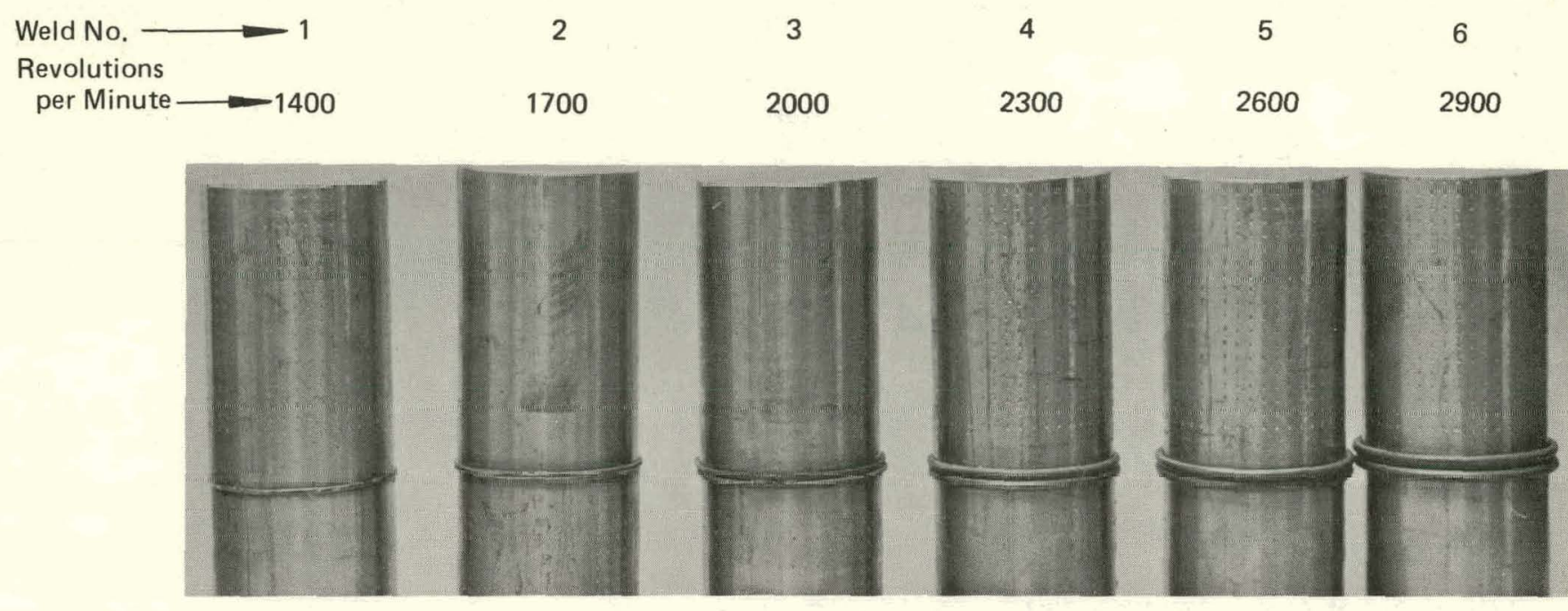

$14813-7$

(a) - Moment of Inertia $=2.14$ kilogram-meters ${ }^{2}$. Axial Pressure $=1.32$ megapascals.

(b) - Moment of Inertia $=2.14$ kilogram-meters ${ }^{2}$. Rotational Speed $=2900$ revolutions per minute.

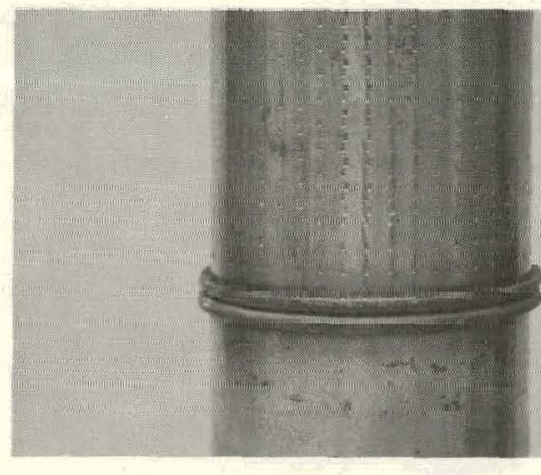

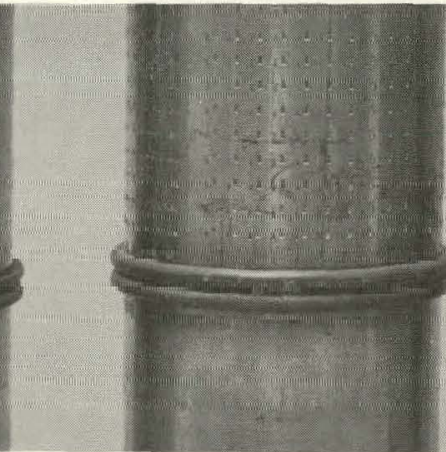

1.09

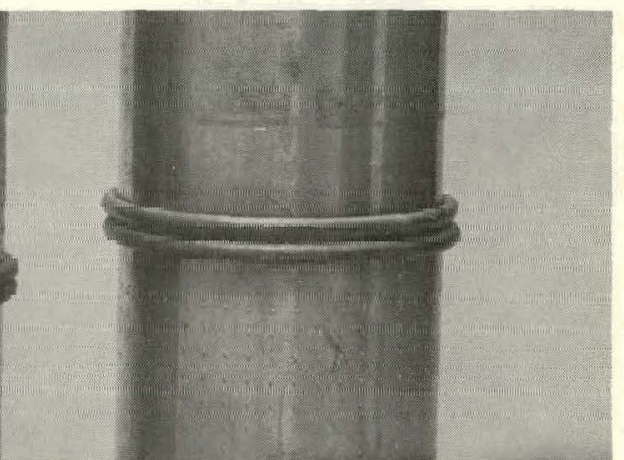

$1481.3-8$ 6 1.32

FIGURES 2(a) and (b). Friction Welds in Stainless Steel (Type-304L).

data are summarized in Figure 3. Each point is the mean of two measurements approximately 180 degrees apart on the same weld.

Figure 3 shows that, in the range of parameters investigated, increased rotational speed causes greater upset, flash, and HAZ width. Bond width is not related to rotational speed. Increased axial pressure during welding does not appreciably affect the HAZ width, bond width, or flash, but does increase the upset.
All of the welds were sound at the polished surfaces. On only one weld (No. 8) was the width of the bond zone less than the wall thickness.

Four tensile coupons were taken from each of the 5 sectioned welds. The coupons were designed to Federal Test Specification 151, Type R-5. Figure 4 gives the resultant mechanical properties.

The coupons from Welds 1 and 4 failed in the base metal; the others failed at or within 1.0 millimeters 


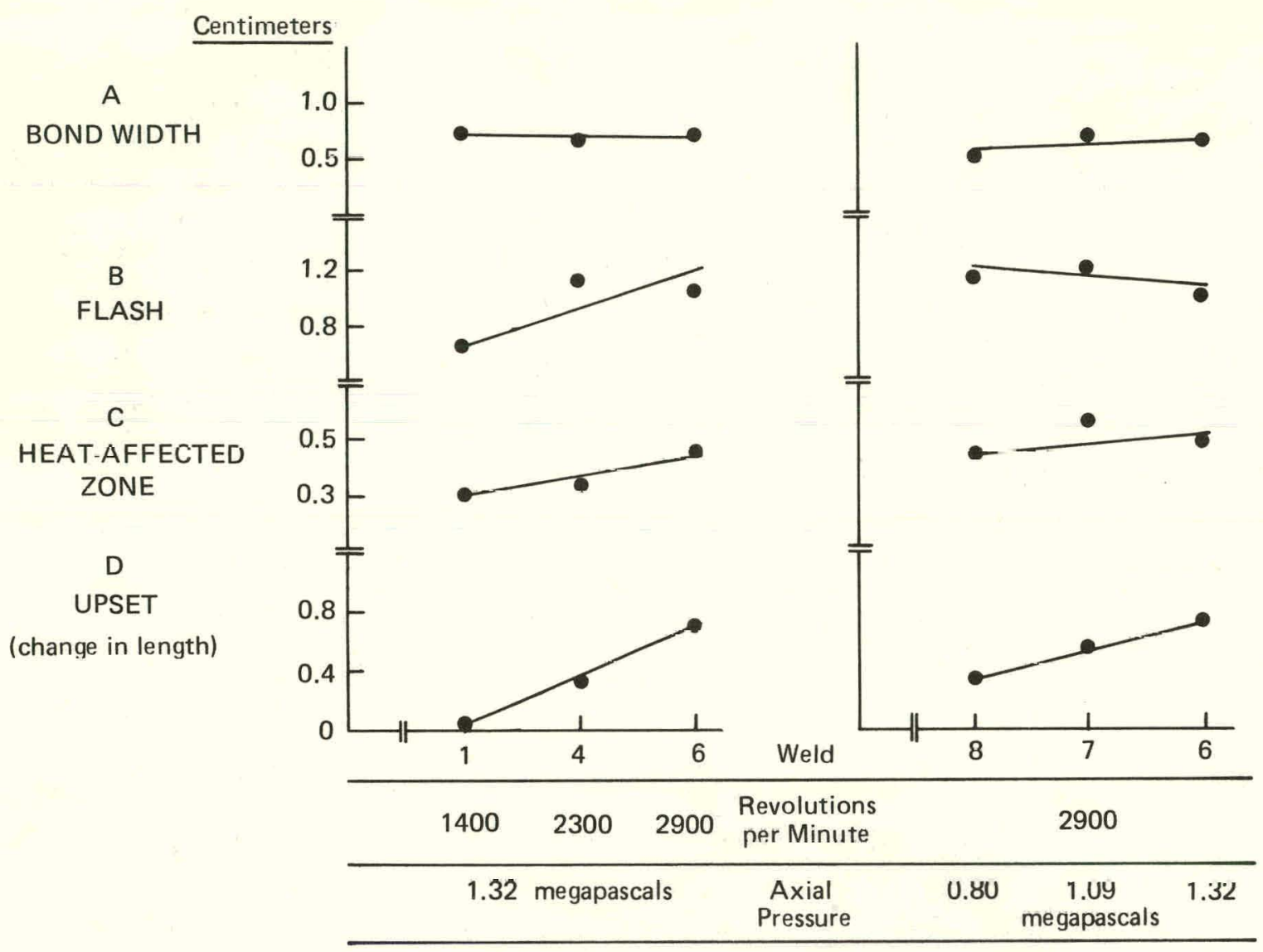

Moment of Inertia $=2.14$ kilogram-meter ${ }^{2}$

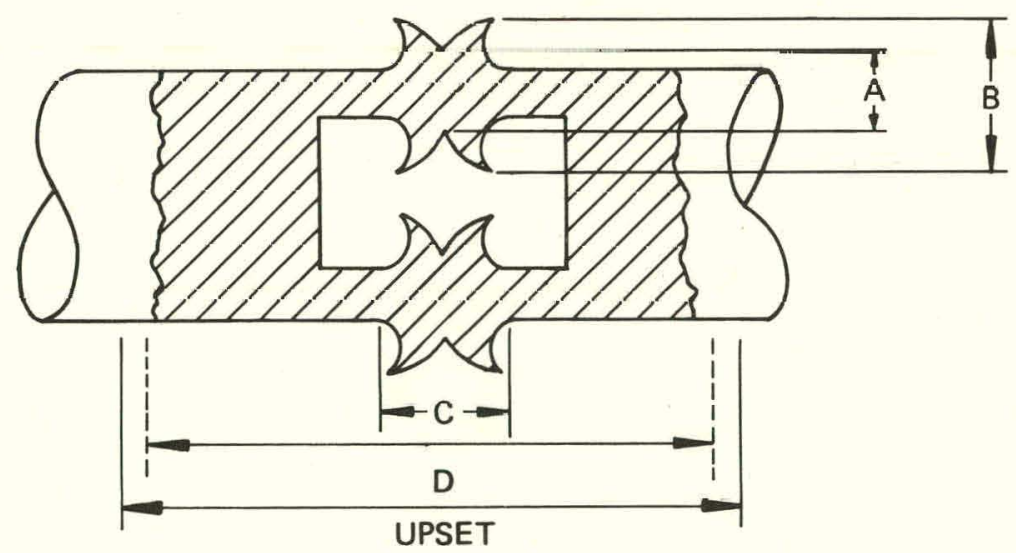

FIGURE 3. Dimensions of Friction Welds in Stainless Steel (Type-304L). 


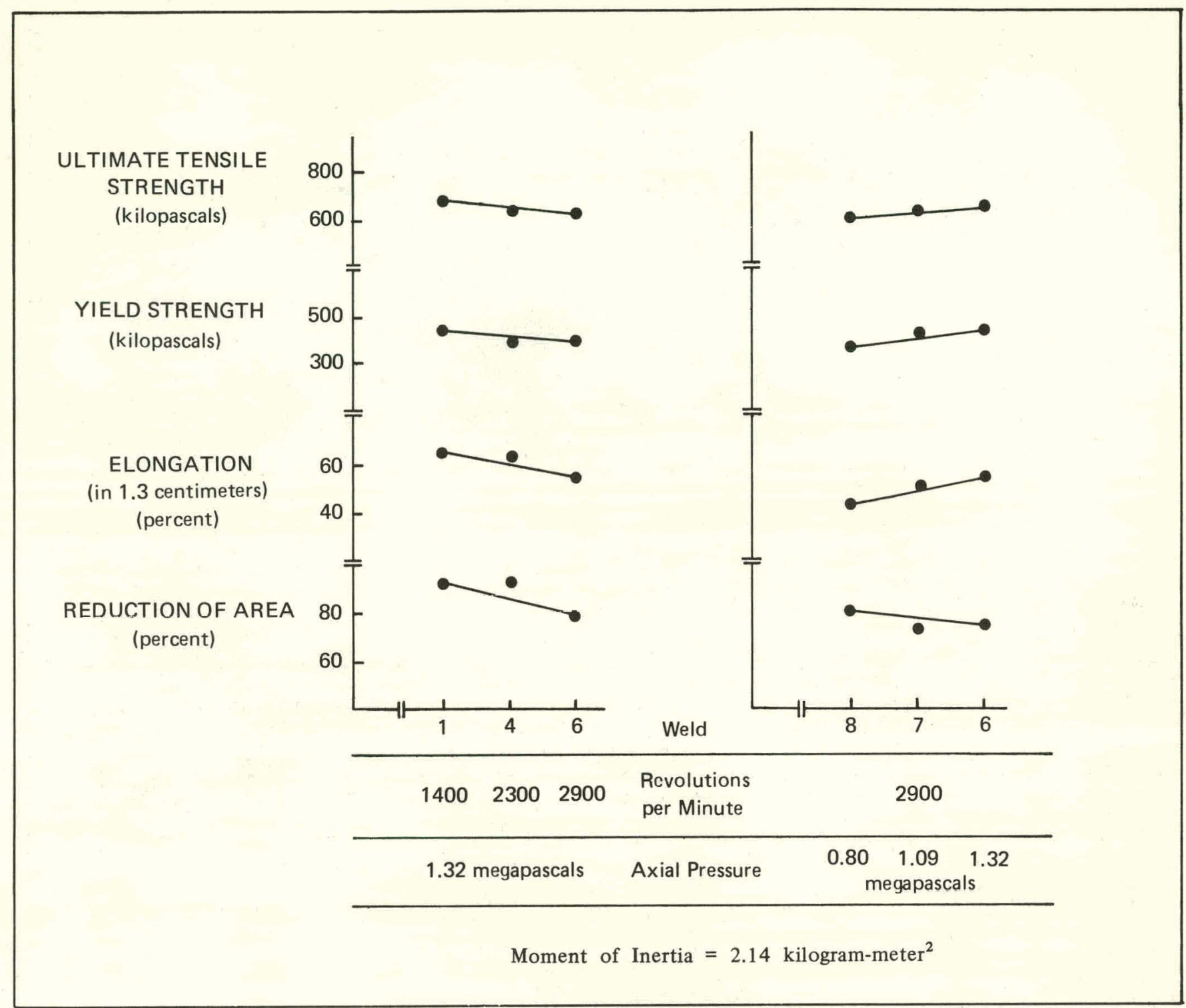

FIGURE 4. Resultant Mechanical Properties of Friction-Welded Stainless Steel (Type-304L).

of the weld. The average base metal properties were:

650 kilopascals - Ultimate Tensile Strength (UTS)

405 kilopascals - Yield Strength (YS)

63.9-percent elongation

87.7-percent reduction of area

Within the range of parameters used, higher rotational speed was slightly detrimental to weld ductility, and weld strength remained virtually unchanged. Increased axial pressure improved weld ductility, but did not appreciably affect weld strength. The range of weld properties was not great. The spread of UTS values was from 600 to 656 kilopascals $(\mathrm{kPa})$ and of elongation values from 42 to 65 percent in the $1.3-\mathrm{cm}$ gauge length.

\section{Aluminum (Type 5083 and 7039):}

Seven welds were made with 5083 aluminum and six welds with 7039 aluminum. The axial force was $246.9 \mathrm{kN}$ (resulting in an interfacial pressure of $383 \mathrm{MPa}$ ), and the moment of inertia was $15.6 \mathrm{~kg} \cdot \mathrm{m}^{2}$. Rotational speeds were from 1300 to $1530 \mathrm{rpm}$. These speeds were chosen by Caterpillar to give good welds rather than a wide range of weld characteristics.

Figures 5(a), (b), (c), and (d) show representative welds of aluminum 5083 and 7039. The illustrated welds were sectioned for macroexamination and mechanical testing. 


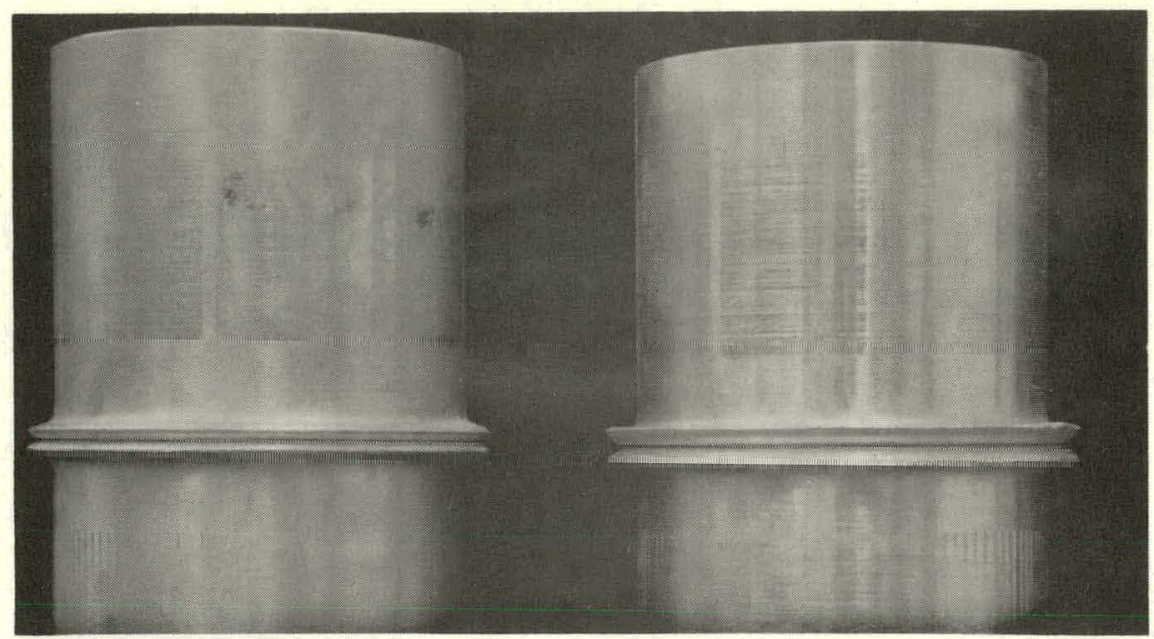

(a) - Weld No. 5083-1,

1430 revolutions per minute. (b) - Weld No. 5083-6,

$14463-1$

\section{Moment of Inertia $=15.6$ kilogram-meters ${ }^{2}$ \\ Axial Pressure $=0.38$ megapascals}

(c) - Weld No. 7039-6, 1300 revolutions per minute. (d) - Weld No. 7039-1, 1430 revolutions per minute.

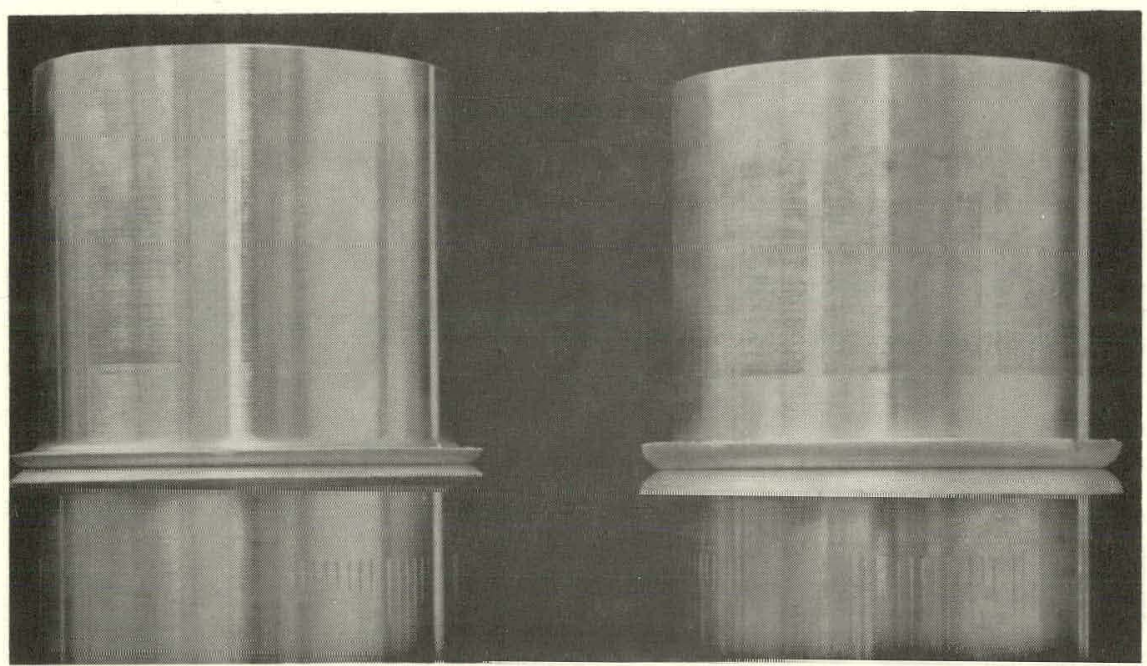

14463-2

FIGURES 5(a), (b), (c), and (d). Firiction Welds in Aluminum (Types 5083 and 7039).

Photomacrographs of the four welds are shown in Figures 6(a), (b), (c), and (d). The cross section of Weld 5083-1, made at $1430 \mathrm{rpm}$, shows that the interface crack extends below the original surface. If the flash were machined off, the reduction in cross section because of the crack would be approximately 14 percent. Also, the sharp crack would normally magnify the loss in serviceability of the weld. The remaining welds were sound at the polished faces and the width of the bond was greater than the wall thickness.

The aluminum-weld dimensions are given in Figure 7. Each point is an average of two measurements from each weld. Each of the measured responses varied only slightly with rotational speed. A wider variation 


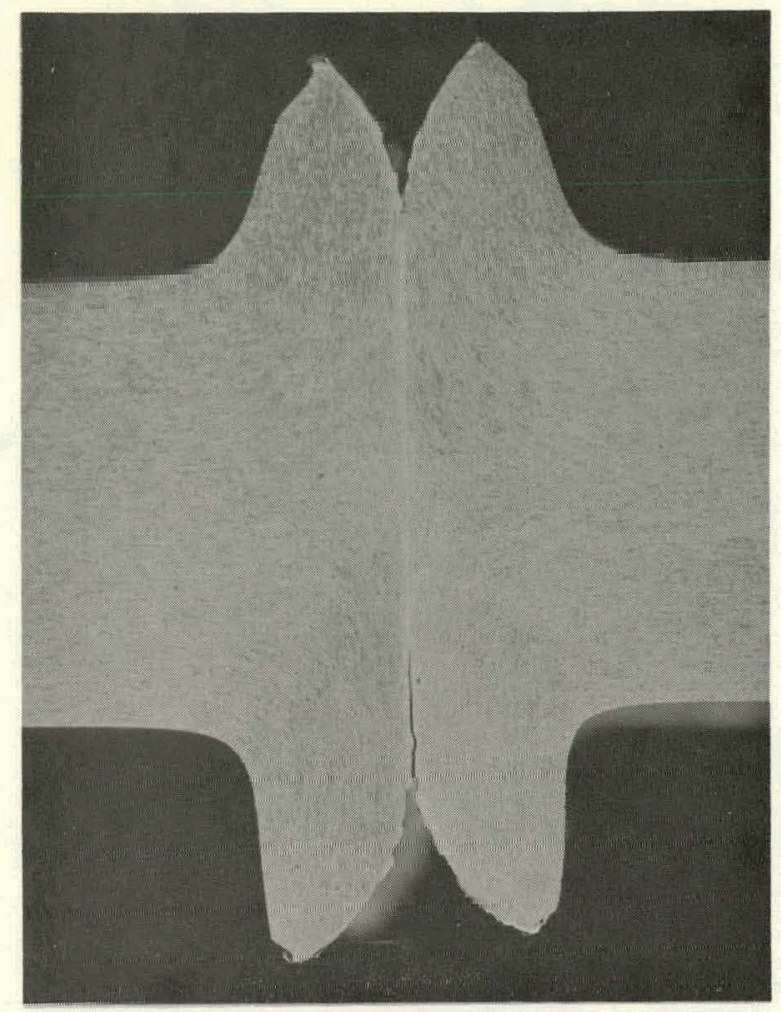

(a) - Weld No. 5083-1

(c) - Weld No. 7039-6

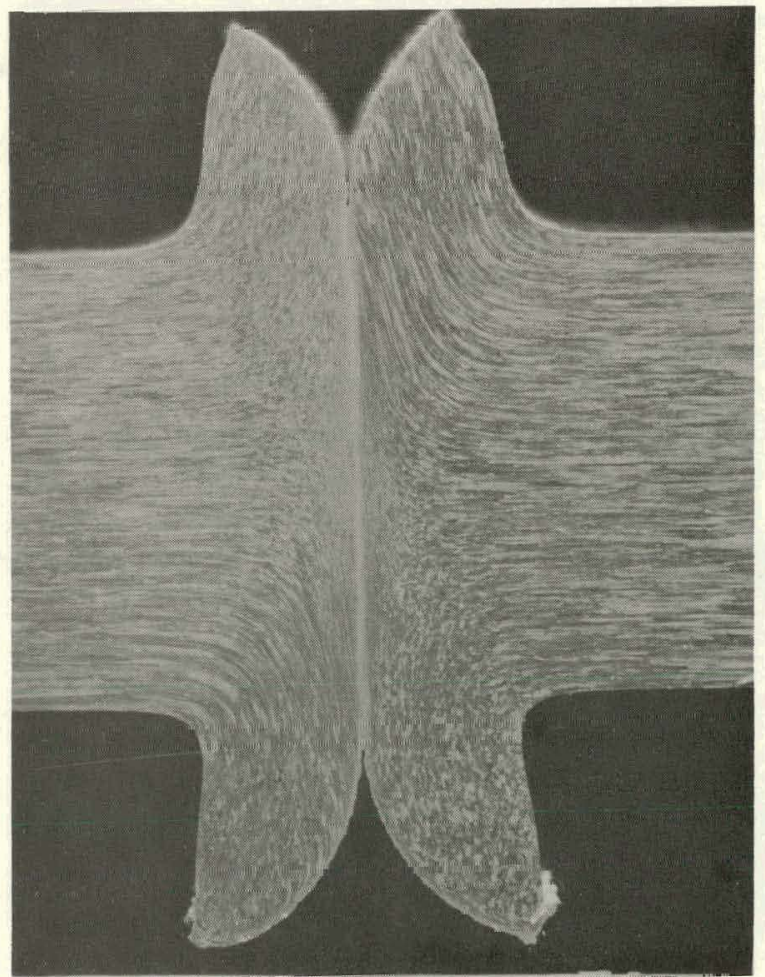

Outside

Diameter

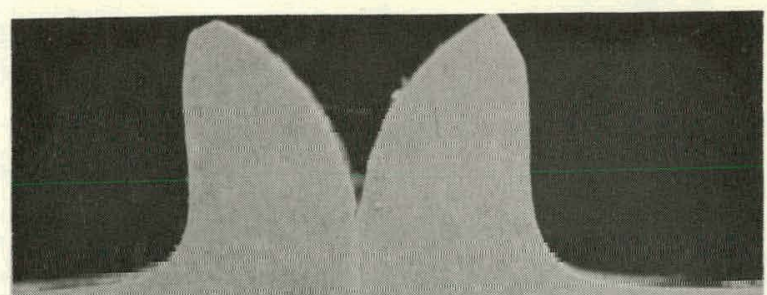

Inside

Diameter

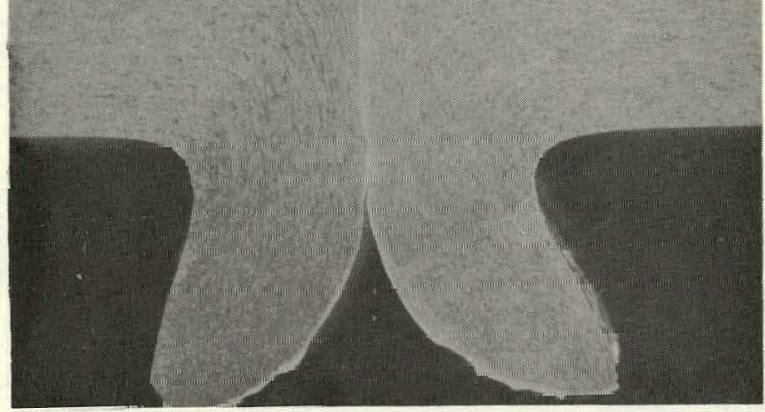

(b) - Weld No. 5083-6

(d) - Weld No. 7039-1

Outside

Diameter

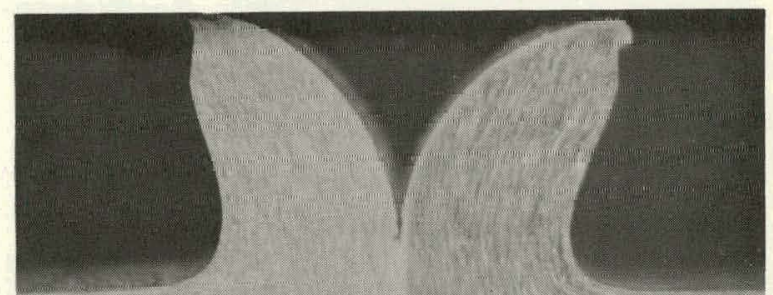

Inside

Diameter

FIGURES 6(a), (b), (c), and (d). Photomacrographs of Friction Welds in Aluminum (Type 5083 and 7039). (Magnification 3.6X; Etch: Hot Ox-Out 536). 


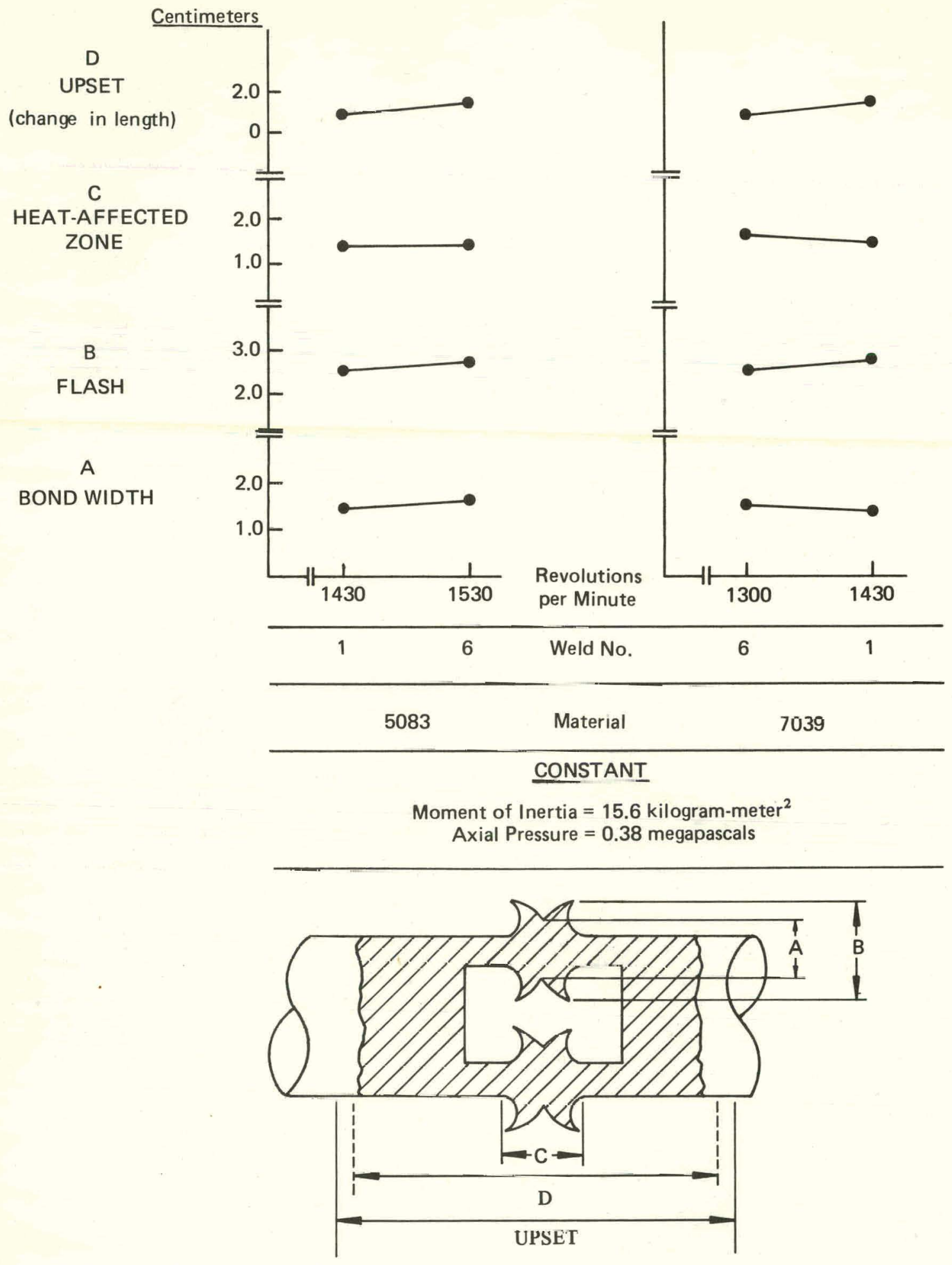

FIGURE 7. Dimensions of Friction Welds in Aluminum (Types 5083 and 7039). 


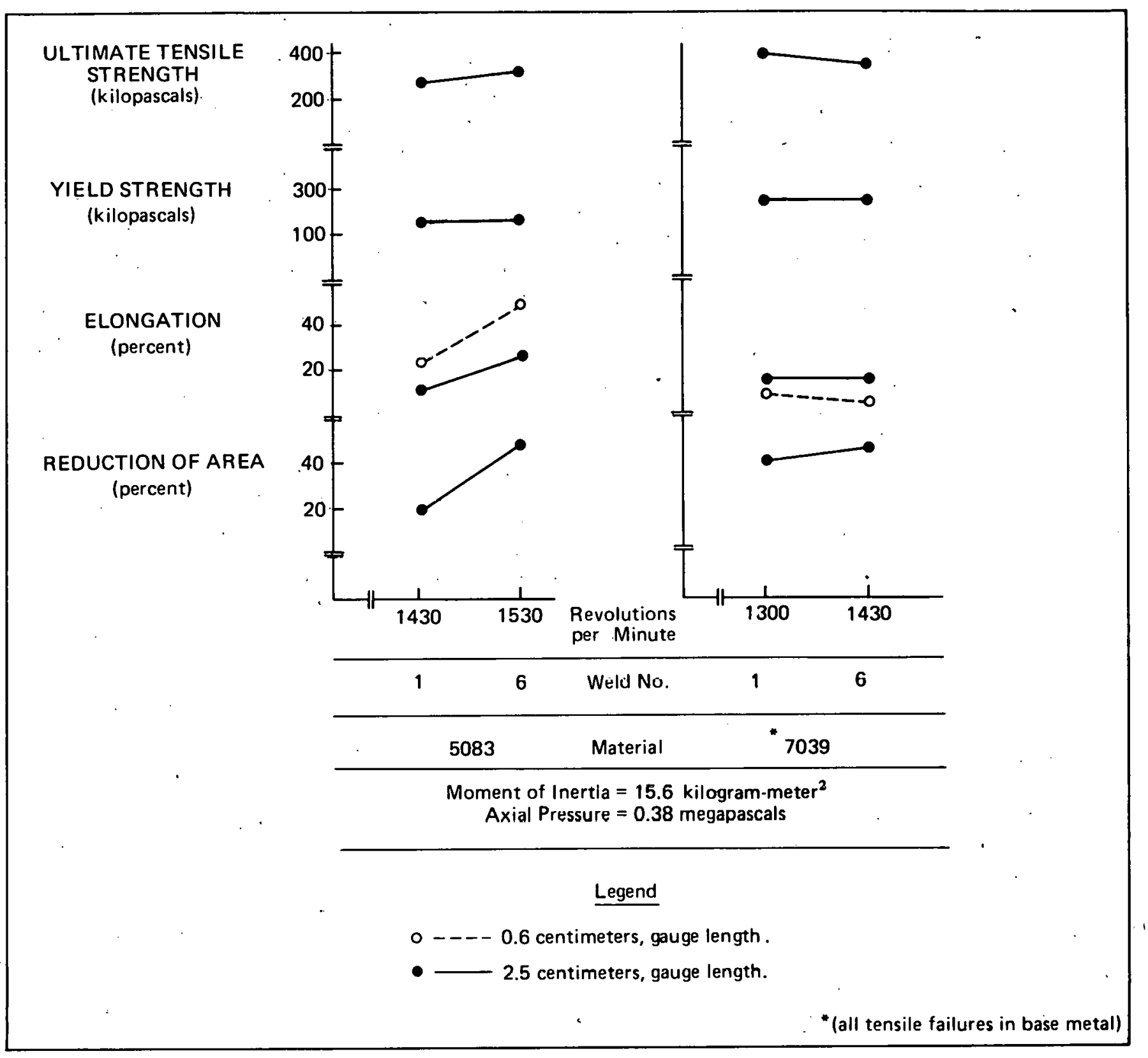

FIGURE 8. Mechanical Propertics of Friction-Welded Aluminum (Types 5083 and 7039). 
TABLE IV. Welding Parameters for Optimum Mechanical Properties.

\begin{tabular}{|c|c|c|c|c|}
\hline Material & Description & $\begin{array}{c}\text { Thrust } \\
\text { (megapascals) }\end{array}$ & $\begin{array}{c}\text { Rotational Sneed } \\
\text { (revolutions per minute) }\end{array}$ & $\begin{array}{c}\text { Inertia } \\
\left(\text { kilogram-meter }{ }^{2}\right)\end{array}$ \\
\hline $\begin{array}{l}\text { Stainless Steel } \\
\text { (Type-304L) }\end{array}$ & $\begin{array}{l}\text { 6.4-centimeter outside diameter } \\
\text { by } 5.1 \text {-centimeter inside } \\
\text { diameter. }\end{array}$ & 1.32 & 1400 & 2.14 \\
\hline $\begin{array}{l}\text { Aluminum } \\
(5083-\mathrm{H} 321)\end{array}$ & $\begin{array}{l}\text { 10.2-centimeter outside diameter } \\
\text { by } 7.7 \text {-centimeter inside } \\
\text { diameter. }\end{array}$ & 0.38 & 1530 & 15.6 \\
\hline $\begin{array}{l}\text { Aluminum } \\
(7039-T 6)\end{array}$ & $\begin{array}{l}\text { 10.2-centimeter outside diameter } \\
\text { by } 7.7 \text { centimeter inside. } \\
\text { diameter. }\end{array}$ & 0.38 & 1430 & 15.6 \\
\hline
\end{tabular}

in speed would he necessary to reflect valid speedresponse relationships.

Figure 8 summarizes the mechanical properties of the aluminum friction welds. The as-welded ductility of the 5083 aluminum increased when the speed was increased from 1430 to $1530 \mathrm{rpm}$. The strength remained unchanged.

All 7039 weld-tensile coupons failed in the base metal so the weld properties were not characterized, except that the strength of the welds was greater than that of the base metal. The average base metal propertles were:

397 kilopascals - Ultimate Tensile Strength (UTS)

245 kilopascals - Yield Strength (YS)

18-percent elongation in 2.5 centimeters

42-percent reduction of area

Although only a small range of conditions, i.e., materials, configurations, and welding parameters were considered in this study, the results are adequate to satisfy the objective. The friction-welding process is a fundamentally good process based on criteria of joint mechanical properties, integrity, and insensitivity to welding parameters.

However, the process is not suitable for joining parts where the substantial flash and the inherent notch would be detrimental. The severe stress riser at the root of the notch, which is also a contaminant trap, and the surface discontinuity created by the flash are objectionable factors for an application where the flash cannot be removed. Removal of the flash eliminates these qualifications.

The upset (change in length) of two replicate welds in hoth aluminum types was reproduc ible within 5 percent. Replicate welds in stainless steel were not made.

\section{CONCLUSIONS}

1. Because of the geometry (flash and inherent notch) of friction welds, the joining process would not be of immcdiate intorest at Rocky Flats. 'The procesa may be applicable to future programs, if the flash can be tolerated or removed.

2. The friction-welding process.could be more desirable than any other method of joining in applications where the flash can be removed or where the flash does not interfere.

3. Within the boundary conditions of this program, the mechanical propertics of friction wclds were shown to approach or exceed those of the base metal. The boundary conditions were: Extruded and annealed 304L stainless steel, 5083-H32l aluminum, 7039-T6 aluminum, cylindrical cross sections of coupons, use of the welding parameters stated, and testing in the as-welded condition.

4. The welding parameters for optimum mechanical properties are given in Table IV. 